\title{
HUBUNGAN ANTARA DUKUNGAN SUAMI DENGAN SIKAP ISTRI PADA DETEKSI DINI KANKER LEHER RAHIM MENGGUNAKAN TES IVA DI PUSKESMAS JATEN II KABUPATEN KARANGANYAR
}

\section{The Correlation Between The Support Husband With Attitude Of Wife On Early Detection Cervical Cancer Used IVA Test in Public Healthy Center Of Jaten II Karanganyar}

\author{
Istiyanah Ayuningtiyas $^{1)}$, Ropitasari ${ }^{2)}$ \\ ${ }^{1)}$ Program Studi DIV Bidan Pendidik, Fakultas Kedokteran Universitas Sebelas Maret Surakarta \\ ${ }^{2)}$ Program Studi DIII Kebidanan Fakultas Kedokteran Universitas Sebelas Maret Surakarta
} e-mail: $\underline{\text { ropita.uns@gmail.com }}$

DOI: 10.13057/placentum.v\%vi\%i.22854

\begin{abstract}
ABSTRAK
Latar Belakang: Kanker Leher Rahim merupakan kanker terbanyak nomor dua yang diderita perempuan di dunia setelah kanker payudara. Pencegahan kanker leher rahim dengan melakukan deteksi dini kanker leher rahim menggunakan tes IVA, harus mendapat dukungan suami.

Metode: pendekatan cross sectional. Populasi penelitian ini adalah Pasangan usia subur dengan umur $\geq 30$ tahun di wilayah Puskesmas Jaten II Kabupaten Karanganyar, teknik pengambilan sampel dengan simpel random sampling dan sample sebanyak 59 responden. Dilakukan dengan menyebar langsung kuesioner kepada responden.

Hasil: Ada pengaruh yang positif antara dukungan suami dengan sikap istri dalam melakukan tes IVA dengan nilai statistic signifikan $\mathrm{p}=0.42$. Hasil koefisien korelasi $\mathrm{r}$ $=0,105$ menunjukkan kekuatan sedang dengan arah korelasi yang positif bermakna antara dua variabel yang diuji.

Kesimpulan: Suami yang memberikan dukungan baik sebesar(61\%)dansikapistri yang positif sebesar $(71,2 \%)$ mampu menjelaskan keikutsertaan dalam pemeriksaan IVA. Disarankan bagi tenaga kesehatan lebih meningkatkan pengetahuan bagi para pasangan usia subur tentang deteksi dini kanker leher rahim melalui pemeriksaan IVA.
\end{abstract}

Kata Kunci: Dukungan suami, sikap istri, Tes IVA 


\section{ABSTRACT}

Background: Cervical cancer is the second most cancer suffered by women worldwide after breast cancer. Prevention of cervical cancer with early detection of cervical cancer using IVA test and the husband's support has an important role to the attitude of the wife in a test IVA.

Method: analytic studycross sectional This population is a partner of childbearing age with age $\geq 30$ years of PHC Jaten II Karanganyar, techniques sampling with simple random sample of 59 respondents. Spreading the questionnaire directly to the respondent.

Results: Therewas a positive influence between husband support the wife's attitude in conducting the test statistic significant IVA test value $=0.042$. The correlation coefficient $r=$ 0.105 showed moderate strength with a significant positive correlation direction between two variables tested.

Conclusion: The husband who provide good support for (61\%) and the positive attitude of the wife $(71.2 \%)$ were able to explain the participation in the examination IVA. Suggested for health personnel increased knowledge among couples of childbearing age about the early detection of cervical cancer through examination of IVA.

Keywords: Support husband, wife attitude, IVA test

\section{PENDAHULUAN}

Organisasi Kesehatan Dunia (WHO) tahun 2010 menyatakan bahwa kanker serviks atau kanker leher rahim merupakan kanker terbanyak nomor dua yang diderita oleh perempuan didunia setelah kanker payudara. Ditemukan sekitar 500.000 kasus baru dengan kematian sebanyak 250.000 setiap tahun. ${ }^{[1]}$

Di Indonesia kanker leher rahim menduduki peringkat pertama, 65\% kondisi pasiennya dalam stadium lanjut. Pada penelitian di tiga belas laboratorium patologi anatomi di indonesia didapatkan frekuensi penderita kanker servik sekitar 18,5\%. Ditemukan sejak umur 25-34 tahun dengan puncaknya terbanyak jumlah penderita berada pada umur 45-54 tahun.

Menurut American College of Obstetrician and Gynecologists, the Royal College of Obstetricians and Gynaecologist, the Canadian Society of Obsterician And Gynaecologist dan the International Federation of gynecologist and obstetrics (FIGO) telah menyimpulkan bahwa penampilan lesi prakanker maupun kanker servik dengan menggunakan inspeksi/penilaian visual dengan bantuan asam asetat menjadi alternatif dengan biaya rendah serta dapat mengendalikan kanker servik di fasilitas sarana kesehatan yang kurang memadai. ${ }^{[2]}$ Angka cakupan skrining kanker servik dengan menggunakan metode IVA di Jawa Tengah masih rendah $20 \%$. $^{[3]}$

Di wilayah Kabupaten Karanganyar angka kejadian kanker servik dari tahun 2011 sebanyak 142 kasus, tahun 2012 sebanyak 75 kasus, tahun 2013 sebanyak 83 kasus, dan tahun 2014 sebanyak 73 kasus. Berdasarkan hasil pengabdian masyarakat tentang "Deteksi Dini Kanker Leher Rahim dengan Metode IVA Test tahun 2012 di Puskesmas Jaten II Karanganyar dengan penduduk sangat padat jumlah penduduk perempuan 11.640 jiwa, 5396 diantara PUS, sementara hanya 364 orang yang telah terjaring pemeriksaan tes IVA selama 12 bulan.

Hasil ini 8,43\% dari target yang ditetapkan puskesmas, yaitu 4316 (20\% total PUS). Terdapat 18 PUS yang mendapatkan pemeriksaan tes IVA setiap bulannya atau 216 PUS setiap tahunnya. Sehingga dapat 
diasumsikan bahwa setiap PUS mendapat skrining tes IVA sekali dalam 20 tahun, seharusnya yang ideal dan optimal pemeriksaan tes IVA dilakukan 3 tahun pada wanita usia 25 - 60 tahun. ${ }^{[4]}$

Peran melakukan tes IVA sangat dipengaruhi oleh suami sebagai pasangan dari wanita. Peranan tersebut dalam bentuk suatu dukungan suami. Dukungan suami pada istri dalam melakukan skrining dini kanker leher rahim sangat penting karena fungsi dari peran suami tentu dipengaruhi oleh tuntutan kepentingan dan kebutuhan yang ada dalam keluarga suami sebagai kepala rumah tangga diwajibkan harus siap dengan tanggung jawab.

Sikap merupakan kesadaran indivi$\mathrm{du}$ untuk menentukan tingkah laku nyata dan perilaku yang mungkin terjadi. Sikap istri dalam melakukan deteksi dini kanker leher rahim sangat berpengaruh untuk menentukan suatu prilaku hidup sehat.

\section{SUBJEK DAN METODE}

Penelitian ini menggunakan metode analitik observasional dengan desain penelitian yang digunakan dalam penelitian Cross Sectional. Populasi /Subjek penelitian yaitu PUS yang melakukan tes IVA di Puskesmas Jaten II, Karanganyar periode April Juni 2016 sebanyak 59 responden memenuhi kriteria inklusi yang melakukan tes IVA di Puskesmas Jaten II dan bersedia menjadi responden secara tertulis.

Tehnik sampling yang digunakan yaitu accidental sampling. Instrumen penelitian menggunakan kuisioner dengan analisis data menggunakan uji Spearman Rank program SPSS 22.0.

\section{HASIL DAN PEMBAHASAN}

Berdasarkan hasil penelitian didapatkan hasil sebagai berikut.

Tabel 1. Distribusi Umur, Pendidikan dan Pekerjaan Responden

\begin{tabular}{lcc}
\hline \multicolumn{1}{c}{ Karakteristik } & $\mathrm{N}$ & $(\%)$ \\
\hline 1. Umur & & \\
$\leq 30$ tahun & 9 & 15,3 \\
>30 tahun & 50 & 84,6 \\
Total & 59 & 100 \\
2. Pendidikan & & \\
Pendidikan Dasar & 2 & 3,4 \\
Pendidikan Menengah & 55 & 93,2 \\
Pendidikan Tinggi & 2 & 3,4 \\
Total & 59 & 100 \\
3. Pekerjaan & & \\
Tidak Bekerja & 36 & 61 \\
Bekerja & 23 & 39 \\
Total & 59 & 100 \\
\hline
\end{tabular}

Berdasarkan tabel diatas dapat diketahui bahwa umur responden paling banyak berada pada rentang usia $>30$ tahun sebesar 93,2\%. Pendidikan responden paling banyak yaitu pendidikan menengah (SMP dan SMA) sebesar 93,2\%. Pekerjaan responden paling banyak adalah pada tidak bekerja yaitu sebesar $61 \%$.

Berdasarkan hasil penelitian mengenai umur responden dapat diketahui bahwa yang mengikuti deteksi dini kanker leher rahim dengan tes IVA umur > 30 tahun sebanyak 50 orang $(84,7 \%)$ Hasil penelitian ini sesuai dengan rekomendasi dari Depkes RI, Tes IVA di fokuskan pada pelayanan kesehatan dan pengobatan untuk perempuan 25-50 tahun. ${ }^{[5]}$

Mengenai tingkat pendidikan responden dapat diketahui bahwa dalam penelitian ini pendidikan menengah lebih banyak dibandingkan dengan pendidikan tinggi, hal ini dapat terjadi dikarenakan program wajib belajar yang di canangkan oleh pemerintah tentang wajib belajar 9 tahun. Sehingga banyak dari responden mengikuti program tersebut namun juga banyak faktor seperti ekonomi, sosial budaya dan lingkungan. Sebagian besar responden memiliki pengetahuan cukup bahkan kurang, hal ini disebabkan karena faktor pendidikan yang relatif masih kurang yaitu pendidikan terakhir SMP 
maupun SMA. Semakin baik tingkat pendidikan yang dimiliki seseorang maka baik pula pengetahuan yang dimiliki sehingga berdampak positif terhadap kesadaran kesehatan dan secara langsung membentuk sikap PUS dalam melakukan tes IVA di puskesmas. ${ }^{[6]}$

Mengenai pekerjaan responden dapat dilihat bahwa responden yang tidak bekerja Wanita yang tidak bekerja lebih banyak mempunyai waktu untuk berinteraksi dengan orang lain dan mendapatkan informasi atau lebih banyakterpapar informasi tentang kanker leher rahim lebih banyak dibandingkan dengan wanita yang bekerja, yang menghabiskan waktunya ditempat kerja.

Istri yang tidak bekerja memiliki waktu luang yang sangat banyak dan dapat menyempatkan waktunya untuk melakukan pemeriksaan dengan tes IVA di puskesmas dan sebaliknya istri yang bekerja lebih banyak menghabiskan waktunya ditempat kerja dan tidak menyempatkan waktunya ditempat kerja dan tidak menyempatkan diri untuk melakukan pemeriksaan kanker leher rahim di puskesmas.

Operasional pemeriksaan IVA di puskesmas hanya dilakukan pada jam kerja seharusnya istri yang bekerja mudah mendapatkan informasi sehingga lebih peduli terhadap kesehatan dan mempunyai waktu yang cukup untuk datang ke puskesmas untuk melakukan tes IVA. ${ }^{[7]}$

Tabel 2. Distribusi frekuensi Dukungan Suami

\begin{tabular}{lcc}
\hline Dukungan Suami & N & $(\%)$ \\
\hline Dukungan Kurang & 23 & 39 \\
Dukungan Baik & 36 & 61 \\
Total & 59 & 100 \\
\hline
\end{tabular}

Berdasarkan tabel 2 dapat diketahui bahwa sebagian besar responden mendapatkan dukungan suami baik sebesar 61\%. Suami yang memberikan dukukan positif terhadap sikap istri akan membentuk suatu prilaku yang baik dan sebaliknya suami yang tidak memberikan dukungan terhadap sikap istri akan membentuk sikap negatif yang ditunjukan oleh istri.

Dukungan suami berupa motivasi, dorongan, informasi, empati ataupun bantuan yang dapat membuat individu lainya merasa lebih tenang dan aman. Dukungan suami dapat mendatangkan rasa senang, rasa aman, rasa puas, rasa nyaman dan membuat individu yang bersangkutan merasa mendapatkan dukungan emosional yang dapat mempengaruhi kesejahteraan jiwa manusia. ${ }^{[8]}$

Tabel 3. Distribusi frekuensi Sikap Istri

\begin{tabular}{lcc}
\hline Sikap Istri & N & $(\%)$ \\
\hline Sikap Negatif & 17 & $28,8 \%$ \\
Sikap Positif & 42 & $71,2 \%$ \\
Total & 59 & $100 \%$ \\
\hline
\end{tabular}

Pada tabel 3 tentang sikap istri dalam melakukan deteksi dini kanker leher rahim dengan tes IVA diketahui bahwa sikap istri yang menujukan sikap positif sebanyak 42 orang $(71,2 \%)$.

Istri yang memiliki sikap positif terhadap tes IVA lebih besar kemungkinan memutuskan melakukan tes IVA. Terbentuknya sikap istri dalam upaya deteksi dini kanker leher rahim dengan tes IVA disebabkan terdapat berbagai faktor yang memengaruhi pembentukan sikap, antara lain: pengalaman pribadi, kebudayaan, orang lain yang dianggap penting, media massa, institusi atau lembaga pendidikan dan lembaga agama serta faktor emosi dalam diri individu. $^{[9]}$ 
Tabel 4. Distribusi Hubungan Antara Dukungan Suami Dan Sikap Istri

\begin{tabular}{llllll}
\hline \multirow{2}{*}{ Dukungan Suami } & \multicolumn{5}{c}{ Sikap Istri } \\
\cline { 2 - 6 } & Negatif & \multicolumn{1}{c}{$\%$} & Positif & $\%$ & Total \\
\hline Dukungan Kurang & 8 & $13,5 \%$ & 15 & $25,5 \%$ & 23 \\
Dukungan Baik & 9 & $15,3 \%$ & 27 & $45,7 \%$ & 36 \\
Total & 17 & $28,8 \%$ & 42 & $71,2 \%$ & 59 \\
\hline
\end{tabular}

Berdasarkan hasil analisis pada tabel 4 dapat diketahui bahwa sebagian responden mendapatkan dukungan suami kurang dengan sikap istri negatif sebanyak 8 orang $(13,5 \%)$.

Dukungan suami yang kurang dapat mempengaruhi sikap istri negatif hal ini dapat terjadi dikarenakan suami dan istri yang memiliki waktu yang sedikit karena disibukkan dengan pekerjaannya baik pekerjaan ditempat kerja ataupun pekerjaan rumah tangga, sehingga kurang pengetahuan dan informasi tentang deteksi dini kanker leher rahim menggunakan tes IVA.

Adanya faktor lain yang dapat mempengaruhi dukungan suami kurang dan sikap istri negatif seperti tenaga medis, sosial budaya dan lingkungan. Tenaga medis yang ada masih kurang dan tidak adanya penyuluhan secara berkala yang di berikan oleh tenaga medis dan dinas kesehatan setempat kepada PUS tentang tes IVA sehingga mempengaruhi dukungan yang diberikan suami dan sikap istri untuk melakukan tes IVA sebagai deteksi dini kanker leher rahim. Sosial budaya yang ada di dekat PUS mempengaruhi dukungan yang diberikan suami sehingga membentuk sikap istri mau atau tidaknya melakukan tes IVA. Lingkungan berperan dalam membentuk pola hidup sehat sehingga PUS mau menjaga kesehatan reproduksi dan adanya rasa malu dan takut saat melakukan tes IVA. ${ }^{[10]}$ Responden yang mendapatkan dukungan suami kurang dengan sikap istri positif sebanyak 15 orang $(25,5 \%)$. Dan dukungan suami yang kurang dengan sikap istri positif dapat terjadi dikarenakan pengetahuan dan informasi yang dimiliki oleh istri lebih baik dari suami tentang tes IVA, informasi yang didapatkan bisa melalui media sosial, majalah, televisi dan tenaga kesehatan sehingga membentuk sikap positif walaupun kurang dukungan dari suami.

Kurangnya dukungan suami selama melakukan tes IVA dikarenakan tidak adanya konseling mengenai kesehatan reproduksi bagi pasangan usia subur yang mengikutsertakan suami sehingga suami kurang peduli akan kesehatan reproduksi pasangannya dan sebagian besar suami beranggapan bahwa kesehatan reproduksi istri adalah kebutuhan istri, sehingga istri berusaha untuk menjaga kesehatan reproduksinya dengan mencari informasi sendiri melalui berbagai media informasi mengenai kesehatan reproduksi khususnya dalam pemeriksaan IVA sehingga membentuk sikap positif meskipun mendapatkan dukungan suami yang kurang.

Responden yang mendapatkan dukungan suami baik dengan sikap istri negatif sebanyak 9 orang $(15,3 \%)$. Responden yang mendapatkan dukungan suami baik dan sikap istri positif sebanyak 27 orang $(45,7 \%)$. Hasil ini menunjukkan bahwa semakin banyak dukungan yang diberikan oleh suami maka semakin positif sikap yang akan ditunjukan oleh istri.

Responden yang mendapatkan dukungan suami baik dengan sikap istri negatif. Hal ini dapat terjadi dimana suami mendapatkan pengetahuan dan informasi tentang tes IVA namun istri yang takut melakukan tes IVA dikarenakan takut mendapatkan hasil yang positif dan tidak nyaman untuk melakukan pemeriksaan dengan tes IVA.

Dukungan suami baik dengan sikap istri ne- 
gatif, dikarenakan istri merasa sulit membagi waktu untuk melakukan tes IVA di puskesmas dikarenakan kesibukan dalam melakukan pekerjaan rumah tangga ataupun pekerjaan ditempat kerja sehingga menyebabkan kurangnya waktu untuk melakukan pemeriksaan dengan tes IVA.

Responden yang mendapatkan dukungan suami baik dan sikap istri positif hal ini dapat terjadi dimana suami dan istri mendapatkan pengetahuan dan informasi kesehat- an reproduksi yang baik tentang tes IVA sebagai deteksi dini kanker leher rahim dan tidak ada rasa takut dan malu dalam melakukan tes IVA. ${ }^{[11]}$

Analisis bivariat diolah menggunakan Spearman Rank untuk mencari hubungan antara dukungan suami dengan sikap istri pada deteksi dini kanker leher rahim dengan Tes IVA dengan bantuan SPSS versi 22, sehingga didapatkan hasil sebagai berikut:

Tabel 5. Hasil Uji Spearman Rank

\begin{tabular}{cclcc}
\hline & & Dukung Suami & Sikap Istri \\
\hline Spearman's rho Dukungan Suami & Correlation & 1.000 & .105 \\
& & Coefficient & & .042 \\
& Sig. (2-tailed) &. & 59 \\
& N & 59 & 1.000 \\
\multirow{2}{*}{ Sikap Istri } & Correlation & .105 &. \\
& & Coefficient & .042 & 59 \\
& Sig. (2-tailed) & 59 & \\
& $\mathrm{~N}$ & &
\end{tabular}

Setelah data penelitian tersebut diolah, selanjutnya dilakukan pengujian data untuk menguji hubungan antara dukungan suami dengan sikap istri dalam deteksi dini kanker leher rahim dengan menggunakan uji Spearman Rank pada tabel 4.8 dapat diketahui bahwahasil tingkat signifikansi 0.042, koefisien korelasi $r=0,105$ dengan menunjukkan bahwa kekuatan sedang dan arah positif terdapat korelasi yang bermakna antara dua variabel yang diuji. Koefisien korelasi menunjukkan bahwa kekuatan hubungan antara variabel adalah sedang. Hal ini dapat terjadi karena ada faktor lain yang tidak diteliti yang bisa mempengaruhi terbentuknya sikap selain dukungan yaitu sosial kebudayaan, lingkungan, media massa, tenaga kesehatan.

Hal ini sesuai dengan tinjauan teori bahwa dukungan suami yang baik akan mampu menciptakan sikap positif istri. Perilaku yang didasari oleh pengetahuan kesadaran, dan sikap yang positif akanlebih baik dari pada perilaku yang tidak didasari oleh pe- ngetahuan. Suami yang dimiliki dukungan yang baik cenderung menganjurkan istrinya untuk melakukan deteksi dini kanker leher rahim dengan tes IVA. ${ }^{[12]}$

\section{KESIMPULAN}

Berdasarkan hasil penelitian yang dilakukan dapat disimpulkan bahwa Suami yang memberikan dukungan baik pada deteksi dini kanker leher rahim dengan tes IVA berjumlah 36 orang (61\%). Sikap Istri pada deteksi dini kanker leher rahim dengan tes IVA menunjukkan sikap positif sebanyak 42 orang $(71,2 \%)$ dan Setelah dilakukan uji analisis statistik dengan menggunakan Spearman Rank diperoleh hasil hasil koefisien korelasi $\mathrm{r}=0,105$ dengan tingkat signifikansi 0.042 menunjukkan bahwa kekuatan korelasi variabel dukungan suami dengan sikap istri melakukan deteksi dini kanker leher rahim dengan tes IVA adalah sedang dan terdapat korelasi yang bermakna antara dua variabel yang diuji. 


\section{SARAN}

Saran yang diharapkan bagi puskesmas bekerja sama dengan dinas kesehatan setempat. dilakukan sosialisasi secara berkala tentang deteksi dini kanker leher rahim dengan tes IVA disekitar wilayah kerja puskesmas baik melalui penyuluhan, penyebaran leatflet atau pemasangan poster serta lebih mengoptimalkan memberikan pendidikan kesehatan kepada para ibu atau wanita usia subur untuk menjaga kesehatan reproduksinya serta mengikutsertakan suami sehingga memberikan dukungan yang baik karena suami berperan penting dalam menentukan sikap istri.

Bagi Pasangan Usia Subur, Pendidikan kesehatan reproduksi sangat penting bagi pasangan usia subur karena sebagai cerminan kesehatan dalam keluarga. Adanya saling mendukung antar suami dan istri dalam menjaga kesehatan reproduksinya dengan cara mendekteksi kanker leher rahim dengan tes IVA di puskesmas. Dukungan suami sangat berperan penting bagi istri baik dalam bentuk dukungan baik ataupun dukungan kurang sehingga menentukan istri dalam bersikap positif dan negatif untuk menjaga kesehatan reproduksinya.

Bagi Peneliti Selanjutnya Pada penelitian selanjutnya diharapkan meneliti faktor yang lebih kompleks pengaruhnya terhadap sikap selain faktor dukungan suami yaitu kebudayaan, lingkungan dan lembaga pendidikan.

\section{DAFTAR PUSTAKA}

1. WHO (2010). Comprehensive Cervical Cancer Prevention And Control:A Healthier Future For Girls and Women. Switzerland.

2. Keshavarzi F, Nankali A, Fakher T, Rezai M, Eslamizadeh N, Bookani SN (2013). Cervical Visual Inspection With Acetic Acid As An Alternative Screening Test For Cervical Cancer
Detection. International Journal of Collaborative Research On Internal Medicine And Public Health. No 1 Vol 5: 62-63

3. Jero (2010). Ancaman Kanker Servik. http//yki.jkt.ac.id/files/2010.pdf.

(Diakses tanggal 17 November 2015)

4. Ropitasari (2012). Deteksi Dini Kanker Leher Rahim Melalui Tes Iva Di Wilayah Puskesmas Jaten II. Universitas Sebelas Maret.

5. Depkes RI (2010). Skrining Kanker Leher Rahim dengan Metode Inspeksi Visual Asam Asestat. www.depkes.go.id/download/kanker.pd f. (Diakses tanggal 15 Desember 2015)

6. Asyari, Muhammad Said (2011). Implementasi UU Sisdiknas No.20 Tahun 2003.

7. Yuliwati (2012). Faktor - Faktor yang Berhubungan dengan Perilaku WUS dalam Deteksi Dini Kanker, Leher Rahim Metode IVA di Wilayah Puskesmas Prembun Kabupaten Kebumen Tahun 2012. Skripsi

8. Setyarini (2009). Faktor-Faktor yang Berhubungan Dengan Kanker leher Rahim Di RSUD Dr.Moewardi Surakarta. Skripsi

9. Indian Journal of Comunity Medicine (2007). Visual inspection with acetic acid (via) screening program: 7 years experience in early detection of cervical cancer and pre-cancers in rural south india. No 40 Vol 3: $203-$ 207.

10. Leya (2015). Sikap PUS Dalam Melakukan Deteksi Dini Kanker Servik. http://lppm.unsil.ac.id/files/2015/02/02 .-Leya-indah.pdf. (Diakses tanggal 25November 2015). 
11. Made N, dkk (2012). Hubungan Tingkat Pengetahuan dan sikap wanita usia subur Dengan pemeriksaan inspeksi visual asam asetat (iva) di puskesmas buleleng. Jurnal Kesehatan Magister Kedokteran Keluarga. Vol 1: Universitas Sebelas Maret.
12. Notoajmojo (2010). Teori Sikap. digilib.unimus.ac.id/download.php/teor i-sikap-Notoajmojo/ (Diakses tanggal 5 desember 2015)

13. Friedman, Marilyn M (2010). Buku Ajar Keperawatan Keluarga: Riset, Teori dan Praktek. Jakarta : EGC. pp: 56-60 